\title{
The prevalence of hepatitis $B$ virus markers in a cohort of students in Bangui, Central African Republic
}

\author{
Narcisse P Komas ${ }^{1 *}$, Souleyman Baï-Sepou ${ }^{1}$, Alexandre Manirakiza', Josiane Léal ${ }^{1}$, Aubin Béré ${ }^{1}$, Alain Le Faou ${ }^{1,2}$
}

\begin{abstract}
Background: Hepatitis B virus (HBV) is the major cause of chronic hepatitis, cirrhosis, and hepatocellular carcinoma. The global epidemiological scenario of HBV infection has been changing rapidly over the last two decades due to an effective immunization programme initiated by the World Health Organization. The objective of this study is to estimate the prevalence of HBV in apparently healthy young people and to identify the risk factors of transmission of the HBV among this population in Bangui.

Methods: Dried blood Spots from 801 adolescent high school and young adult university students were prepared by spotting a drop of whole blood (4 spots) from the same fingerprick onto Whatman filter paper. A blood sample aliquot eluted from DBS was then processed with commercial ELISA tests (Abbott Murex, Dartfort, UK) to detect HBsAg antigen, Anti-HBC and Anti-HBs antibodies).

Results: The overall prevalence was $42.3 \%$ for antibody to hepatitis B core antigen, $15.5 \%$ for HBsAg of which $1.3 \%$ of HBsAg alone. HBV familial antecedents, sexual activity and socioeconomic conditions were the main risk factors of HBV infection encountered in the adolescents and young adults.

Conclusion: These results show for the first time the high prevalence of HBV in apparently healthy young people in Bangui. This high prevalence is age- and sex-independent. Transmission risk factors were a familial antecedent of HBV, no utilisation of condoms and public scholarship. To lower HBV prevalence, an adequate program of active screening and vaccination for adolescents and young adults should be implemented, along with a universal immunization program.
\end{abstract}

\section{Background}

Hepatitis B virus (HBV) infection represents a major health problem, with 2 billion people infected worldwide and more than 400 million chronic carriers of HBV. Globally it causes about 1.2 million deaths per year due to various complications including chronic hepatitis, cirrhosis, and liver cancer [1-4]. It is estimated that about one third of the infected individuals have symptoms and/ or biological evidence of hepatitis. It is well established that the earlier the contamination, the higher the risk of chronic infection which is as high as $90 \%$ in infected infants. Chronic carriers have a high mortality rate due to complications. In Sub-Saharan Africa, the prevalence

\footnotetext{
* Correspondence: npkomas@yahoo.fr
'Viral Hepatitis Laboratory, Institut Pasteur de Bangui, PO Box 923 Bangui,

* Correspondence: npkomas@yahoo.fr
'Viral Hepatitis Laboratory, Institut Pasteur de Bangui, PO Box 923 Bangui, Central African Republic
}

(c) 2010 Komas et al; licensee BioMed Central Ltd. This is an Open Access article distributed under the terms of the Creative Commons Attribution License (http://creativecommons.org/licenses/by/2.0), which permits unrestricted use, distribution, and reproduction in any medium, provided the original work is properly cited.

of HBV surface antigen (HBsAg) is $3-20 \%$ and markers of past exposure ranging from $60-99 \%$ [5].

The Central African Republic (CAR), located in tropical Africa, is considered an area of high endemicity for HBV infection with most HBV strains that belong to the West African genotype E [6]. The transmission of this disease is believed to be mainly by sexual, vertical and intrafamilial routes [7]. Previous study on young sexually active adults, examined in a Public health clinic for sexually transmitted disease in CAR, has shown a high prevalence of $\mathrm{HBsAg}(14 \%)$ with a prevalence of anti$\mathrm{HBc}$ antibodies at $89 \%$ [8]. In addition, a survey carried out in the pediatric hospital of Bangui revealed a prevalence of $22.3 \%$ in children under 16 years of age with a precocity of the infection (25\% of the children were infected before they reached one year) and a high increase of prevalence (48\%) among children aged of 
10 to 15 [9]. Since these studies have been carried out in the hospital environment they do not obligatorily reflect the prevalence of HBV in the general population. During adolescence, individuals are more prone to risk behaviors such as alcohol abuse, multiple partners and are exposed to sexually transmitted diseases $[10,11]$. Hepatitis B is a preventable disease and it is necessary to establish its importance and distribution among the population in order to evaluate the need for implementing preventive action [12,13]. Although, CAR has a high prevalence of HBV infections, there is for the moment neither a national program of prevention nor national recommendations to limit the transmission of this disease. Thus, the purpose of this survey was to determine the prevalence of HBV in an apparently healthy population and identify the risk factors of infection among adolescents and young adults in order to propose strategies of prevention.

\section{Methods}

\section{Study population}

The study was carried out from $1^{\text {st }}$ to $28^{\text {th }}$ of February, 2007 in seven (7) public and five (5) private high schools, randomly selected, and in the University of Bangui. The objectives of the survey were presented to each high school Director and to the General Secretary of the University in order to obtain their authorization.

To evaluate the prevalence and risk factors for HBV infection, the study sample was calculated using the Schwartz formula on the basis of an alpha error of $5 \%$, an expected HBsAg prevalence of $22.3 \%$ [9] and a precision of $3 \%$. In accordance with these data, the required sample size was 740 individuals.

A total of 801 individuals were sampled and completed the questionnaire. In addition to the standard questions on socio-economic status, the following risk factors were investigated: HBV familial antecedents (at least one of parents or siblings was a chronic HBV carrier), tattooing, body piercing, alcohol and illicit drug consumption, number of sexual partners, age of first sexual intercourse. Individuals were assured that the obtained information would not be shared with parents (except in the case of students under 18 years of age), school staff and any other person. The students were almost evenly distributed among the 8 districts of the city and the adjacent town of Bimbo.

\section{Ethical approval}

Informed consent was obtained from all individuals. For subjects under 18, parental consent was required. Each participant and/or parent was informed of the results of the serology. The study was approved by the Scientific Committee of the Faculty of Medicine of the University of Bangui.

\section{Specimen Collection}

Dried blood spots (DBS) were prepared by spotting a drop of whole blood (4 spots) from one finger prick onto Whatman filter paper. Blood collections were carried out in the amphitheatres and/or the classrooms. Once air-dried, the filter papers were sealed in plastic bags, brought to the laboratory and stored at $-20^{\circ} \mathrm{C}$ in the presence of a desiccant until testing.

\section{Serological assays}

In this study, we slightly modified the technique of DBS that was previously described [14]. Briefly, blood samples were extracted from DBS by punching one bloodstained circle of $6 \mathrm{~mm}$ diameter from the filter paper, and then incubated overnight in $500 \mu \mathrm{l}$ PBS at room temperature. After a rapid centrifugation, the supernatant was used for testing. HBs antigen Version 3, Anti-HBc and Anti-HBs antibodies (Abbott-Murex Biotech Ltd, Dartford, Kent, UK) were performed according to manufacturer's recommendations on all samples. The value of the technique was ascertained by comparing the results obtained with sera and filter paper eluate for 15 individuals. All HBsAg positive results were confirmed (Murex HBsAg Confirmatory test, Version 3). The interpretation of the serological assays was as stated by the manufacturers.

\section{Statistical analysis}

Epi-Info Version 2000 (CDC, USA \& WHO Geneva, Switzerland) software was used for analyzing data: prevalence, 95\% confidence intervals and Chi-square test for the comparison of variables and association of HBV positivity and risk factors. Statistical significance was assessed at $p<0.05$.

\section{Results}

The surveyed population of adolescents and young adults consisted of 455 (56.7\%) males and 347 (43.3\%) females (sex ratio $=1.31$ ). Age ranged from 14 to 48 years (mean 20.8, SD \pm 4.1 ). They were from public $(336,41.9 \%)$ and private $(239,29.8 \%)$ high schools and the University of Bangui (226, 28.2\%).

The preliminary tests of 15 samples from DBS have shown a good correlation of results with the test performed on sera but for one patient. However, confirmatory test showed that it was a false HBs positivity (table 1). Among the young adults, 339 were $\mathrm{HBV}$ positive (Table 2), and of these 124 (15.5\%) had an active infection. Ten $(10,1.3 \%)$ had "HBsAg only". Prior infections were detected in 215 individuals (26.8\%) of whom only $8(1.0 \%)$ had anti-HBs. None of the 801 individuals was vaccinated against $H B V$.

There was no statistical difference between the prevalence of HBV infection markers according to sex, age (Table 3) or place of residence. However, students from 
Table 1 Comparison of the sensitivity and specificity of HBsAg and Anti-HBc Ab detection in DBS and sera

\begin{tabular}{lccccccc}
\hline & & \multicolumn{2}{c}{ Positive } & Negative & \multicolumn{2}{c}{$\begin{array}{c}\text { Confirmatory } \\
\text { test }\end{array}$} \\
\cline { 2 - 8 } & $\mathbf{n}$ & Sera & DBS & Sera & DBS & Sera & DBS \\
\hline $\mathrm{HBsAg}$ & 15 & 9 & 10 & 6 & 5 & 9 & 9 \\
Anti-HBc Ab & 15 & 10 & 10 & 5 & 5 & $\mathrm{NA}^{*}$ & $\mathrm{NA}$ \\
Anti-HBs Ab & 5 & 1 & 1 & 4 & 4 & $\mathrm{NA}$ & $\mathrm{NA}$ \\
Sensitivity & $\mathrm{HBsAg}$ & $100 \%$ & & & & & \\
& Anti-HBc Ab & $100 \%$ & & & & & \\
Specificity & $\mathrm{HBsAg}$ & $83.3 \%{ }^{\#}$ & & & & & \\
& Anti-HBc Ab & $100 \%$ & & & & \\
\hline
\end{tabular}

*NA: Not Applicable

${ }^{\#} 100 \%$ after confirmatory test.

Table 2 Prevalence of hepatitis B markers detected in 801 students in Bangui

\begin{tabular}{|c|c|c|c|}
\hline $\begin{array}{l}\text { Serological markers } \\
\text { present }\end{array}$ & & $\begin{array}{l}\text { Number (\% of } \\
\left.\text { total }^{*}\right)\end{array}$ & $95 \% \mathrm{Cl}$ \\
\hline \multirow[t]{3}{*}{$\mathrm{HBsAg}$} & & $124(15.5)$ & $13.0-18.0$ \\
\hline & HBsAg only & $10(1.3)$ & $0.5-2.0$ \\
\hline & $\begin{array}{l}\text { HBsAg, Anti- } \\
\mathrm{HBC} A \mathrm{~b}\end{array}$ & $114(14.2)$ & $11.8-16.6$ \\
\hline Anti-HBC Ab only & & 207 (25.8) & $23.1-29.3$ \\
\hline $\begin{array}{l}\mathrm{HBsAg} \text { and/or Anti- } \\
\mathrm{HBCAb}\end{array}$ & & $331(41.3)$ & $37.9-44.7$ \\
\hline $\begin{array}{l}\text { Anti-HBs Ab/Anti-HBC } \\
\mathrm{Ab}\end{array}$ & & $8(1.0)$ & $1.2-6.2$ \\
\hline
\end{tabular}

district 4 which is characterized by a large population living in close proximity had the highest prevalence of HBV infections while those from Districts 2 and 3 with a higher living standard had the lowest.

Among the risk factors (Table 4), there was no association between HBV infection and socio-economic conditions. However, the prevalence of HBV infection markers was significantly higher: i) in orphans (OR 1.47, 95\% CI 1.05-2.06), ii) in individuals attending public high school in comparison to those from private high school or the university (OR 2.8, 95\% CI 1.95-4.03; OR 2.38, 95\% CI 1.66-3.43), iii) when HBV familial antecedent are reported (OR 1.80, 95\% CI 1.21-2.93) and

Table $3 \mathrm{HBV}$ positivity according to sex and age among 801 students in Bangui

\begin{tabular}{ccccccc}
\hline \multicolumn{3}{c}{ Male } & \multicolumn{3}{c}{ Female } \\
\hline $\begin{array}{c}\text { Age } \\
\text { (Years) }\end{array}$ & Total & $\begin{array}{c}\text { *HBV+ } \\
(\%)\end{array}$ & 95\% Cl & Total & $\begin{array}{c}\text { *HBV+ } \\
\mathbf{( \% )}\end{array}$ & $\mathbf{9 5 \% ~ C l}$ \\
\hline $14-19$ & 149 & 41.6 & $33.6-49.6$ & 195 & 43.1 & $36.1-50.1$ \\
$20-25$ & 234 & 43.2 & $36.8-49.6$ & 125 & 48.0 & $39.2-56.8$ \\
$\geq 26$ & 71 & 32.4 & $21.2-43.6$ & 27 & 33.3 & $14.7-51.9$ \\
Total & 454 & 40.1 & $35.5-44.7$ & 347 & 45.2 & $39.9-50.5$ \\
\hline
\end{tabular}

${ }^{*} \mathrm{HBV}(+)$ : one of the markers ( $\mathrm{HBs} A g$, anti-HBc $\mathrm{Ab}$ and anti-HBs $\mathrm{Ab}$ ) at least is positive
Table 4 Risk factors of HBV in 801 students in Bangui (univariate analysis)

\begin{tabular}{lcccc}
\hline Variable & $\mathbf{n}$ & \%HBV+ & Odds Ratio & $\mathbf{9 5 \%} \mathbf{~ C l}$ \\
\hline $\begin{array}{l}\text { Parents } \\
\quad \text { One or two are dead }\end{array}$ & 196 & 49.5 & 1.47 & $1.05-2.06$ \\
$\quad$ Both are alive & 605 & 40 & 1 & \\
$\begin{array}{c}\text { Education } \\
\quad \text { Public High School }\end{array}$ & 336 & 55.7 & 1 & \\
$\quad \begin{array}{c}\text { Private High School } \\
\quad \text { University }\end{array}$ & 239 & 31 & 2.80 & $1.95-4.03$ \\
$\quad 226$ & 34.5 & 2.38 & $1.66-3.43$ \\
HBV Familial antecedent & & & & \\
$\quad$ Yes & 100 & 56 & 1.80 & $1.21-2.93$ \\
$\quad$ No & 701 & 40.4 & 1 & \\
Marital Status & & & & \\
$\quad$ Single & 701 & 42.4 & 0.99 & $0.63-1.64$ \\
$\quad$ Married & 100 & 42 & 1 &
\end{tabular}

Tattooing

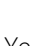

No

27

42.4

1.00

$0.43-2.83$

Dental Surgery

774

40.7

1

0.87-1.76

185

38.4

1.24

No

616

43.5

Surgery

Yes

No

$\begin{array}{ll}76 & 32.9\end{array}$

0.16

$0.11-0.22$

Body piercing

$$
\text { Yes }
$$

564

43.3

1

$0.92-1.74$

Blood Transfusion

Alcohol Use

\section{Yes}

No

33
768

39.4

1.13

1

Yes

No

372

43.5

0.91

$0.68-1.22$

Injecting Drug Use

Yes

429

41.3

No

$8 \quad 37.5$

NA

Use of Condoms

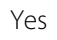

No

$793 \quad 42.4$

(1)

Yes

No

Sexual experience

$\begin{array}{ccccc}\text { Yes } & 631 & 43.7 & 1.76 & 0.53-1.09 \\ \text { No } & 170 & 37.1 & 1 & \end{array}$

Years since first intercourse

$\begin{array}{ccccc}\leq 1 & 126 & 44.4 & 1 & \\ 2-3 & 177 & 48 & 0.87 & 0.53-1.41 \\ >3 & 321 & 40.5 & 1.18 & 0.76-1.82\end{array}$

Number of sexual Partner

One (1) partner

\begin{tabular}{lcccc} 
(Male) & 94 & 47.9 & 1.02 & $0.58-1.81$ \\
(Female) & 126 & 48.4 & 1 & \\
r more partner & & & & \\
$\quad$ (Male) & 312 & 38.2 & 1,87 & $1.15-3.03$ \\
(Female) & 99 & 53.3 & 1 & \\
\hline
\end{tabular}

${ }^{*} \mathrm{NA}=$ Not Applicable because number $(\mathrm{n})$ is very low 
iv) finally, in individuals who did not use condoms (OR $1.69,95 \%$ CI $1.17-2.43)$ and have 2 or more sexual partner (OR1.87, 95\% CI 1.15-3.03). Other variables that may be considered as high risk factors such as body piercing, tattooing, marital status, profession of parents, alcohol use, years since first sexual intercourse, surgery, dental surgery or blood transfusion were associated to a moderate higher risk of HBV infection without any statistical significance. Finally, it has to be noted that three of the eight people who had admitted the use of an illicit drug were infected.

\section{Discussion}

In our study, serology was the method of choice as it permits a direct evaluation of the prevalence of HBV infections. The dried blood spot technique gives reliable results with sensitivity and specificity almost identical to serum testing. The collection of blood samples is made easy using finger pricks [15-17]. It reduces the cost of the survey and, as it is almost painless, the risk of refusal is minimized (and there was none in this study). The high prevalence of $\mathrm{HBV}$ infection in young individuals from Bangui, with global HBsAg prevalence of $15.5 \%$ clearly confirms the complete absence of any program to combat hepatitis $\mathrm{B}$. This is evident when comparing the rates in developed countries $[18,19]$, or countries who have implemented prophylaxis of this infection [20-22]. The vaccination of infants in the first 11 months will have only a limited impact unless a follow up is implemented and the prevention of mother to infant transmission put in place.

The population of adolescents and young adults in our study consist of all 8 districts of Bangui and from the adjacent city of Bimbo. To determine the risk factors of transmission of $\mathrm{HBV}$ in the chosen population, it would be better to survey separately each social level of the population, but, in the absence of any HBV education program in the country it would be difficult to reach the entire population. Public high schools in Bangui and the University are attended by student whatever their social status and the place they live in. However, private schools accept solely students who can afford the fees and are thus from middle and upper class. They represent at least $30 \%$ of the adolescent and young adult population. Thus, our study population represents the educated adolescents and young adults living in an urban environment. This population is selected and thus do not reflect the general population. A survey should be conducted with the help of the health authorities to evaluate the rate of $\mathrm{HBV}$ infection in the general population.

The prevalence of HBsAg in our study was not correlated with age. As indicated by the survey in children [9] most chronic infections in Bangui are related to mother to infant transmission or infection at a young age. Acquired infection, mainly sexually, in later age, resolves for it most part spontaneously. Thus the prevalence of anti-HBc increases regularly while the one of HBsAg augments only moderately.

Only $3.7 \%$ of participants have detectable anti-HBs antibodies in this study. This observation requires further investigation to determine the reason why this study shows such a very low detectable anti-HBs antibody level. This is not due to a loss of the sensitivity of the DBS as it had been shown with the preliminary tests as well as observations from other studies [14,17]. Although infection in neonates can explain an immunotolerance phenomenon, the absence of anti-HBs in young adults is puzzling and requires further investigation. This may be due to some characteristics of the population. A variant of the HBs-antigen may be readily detected while the corresponding antibodies are not. It remains to be determined if this observation is related to the E genotype [6,23].

In our study, there was no evident direct association between socio-economic conditions and HBV infections. However, although not significant, district with low income correspond to higher proportion of infected individuals. Thus it is likely that geographic origin and income are two dependant variables. Nevertheless the role of socio-economic status is reinforced by the higher prevalence of infection in students from public high schools in which they are accepted free of charge. This is not the case in private schools, which only part of the population can afford to attend, as already observed [24]. The same conclusion can be made for the students who attend the university.

In this study, HBV infection may also be mainly linked to sexual transmission. In fact, risk factors, such as lifetime number of sexual partners $>2$ and non use of condoms, were associated with $\mathrm{HBV}$ in the univariate analysis. This is not surprising as sexual transmission is an important route of HBV infection. The role of drug use cannot be estimated as only eight students declared use of injecting-drugs of whom three were infected with $\mathrm{HBV}$. Intrafamilial transmission may also play a role in HBV infection of young people as living in a family in which one member is infected is also a risk factor $[25,26]$. Dental care is a moderate risk factor, likely because of lack of hygiene. Contrarily, hospitalization seems to have no role in HBV transmission.

\section{Conclusion}

This survey, the first performed in a population of young healthy educated adults in Bangui, indicates a high prevalence of HBV infection. The increase in anti$\mathrm{HBc}$ prevalence in teens as previously described [9] and the one we observed are in favor of sexually acquired 
infection. However the environment plays an important role as the absence of education and the low income favor HBV infection. Altogether, the high prevalence of infected young adults reflects the absence of health policy for fighting against this disease. This is alarming and taking into account the high risk of HBV transmission in the country by health authorities may reduce dramatically the burden of this disease. Information of the population, focusing mainly on adolescents, vaccination not only of infants but also of the entire population and a prophylaxis of mother to infant transmission are to be implemented.

\section{List of abbreviation}

Anti-HBc Ab: anti-hepatitis B core antibody; Anti-HBs Ab: anti-hepatitis B surface antibody; Anti-HDV antibody: Anti hepatitis Delta virus antibody; CAR: Central Africa Republic; CDC: Center for Diseases Control; DBS: Dried blood spots; HBsAg: Hepatitis B surface antigen; HBV: Hepatitis B virus; PBS: phosphate buffer saline; SD: standard deviation; WHO: World Health Organization

\section{Acknowledgements}

We are grateful to the staffs of the high schools and the University of Bangui who provided access to the students as well as to the students and their parents for their cooperation. We thank Emmanuel Fandéma, Serge NGaïré, Sylvain Féïtou, Amina Sépou and Romaine Yabougnawo for their help in blood sample collection and also Ms Denise Cook for revising written English.

\section{Author details}

${ }^{1}$ Viral Hepatitis Laboratory, Institut Pasteur de Bangui, PO Box 923 Bangui, Central African Republic. ${ }^{2}$ New Affiliation address: Laboratoire de Virologie, CHU de Nancy, Hôpital de Brabois-adultes, 54511 Vandoeuvre-lès-Nancy, France.

\section{Authors' contributions}

NPK designed the study and directed its implementation, supervised all the field activities, analyzed and interpreted data and redacted the manuscript. ABS helped to supervise the field activities, contributed to the acquisition of data by preparing the questionnaire and by participating to the collect of DBS. AM contributed to the analysis and interpretation of the data. $J$ and $A B$ contributed to the acquisition of data by performing ELISA test and participated to the collection of the DBS. ALF contributed to the analysis and interpretation of the data and to the redaction of the manuscript. All authors approved the final version of the manuscript.

\section{Competing interests}

None of the authors in this study has any financial personal relationship with any organization that could influence (bias) this work.

Received: 18 January 2010 Accepted: 29 July 2010

Published: 29 July 2010

\section{References}

1. Hou J, Liu Z, Gu F: Epidemiology and prevention of hepatitis B virus infection. Int J Med Sci 2005, 2:50-57.

2. Lavanchy D: Hepatitis B virus epidemiology, disease burden, treatment, and current and emerging prevention and control measures. J Viral Hepat 2004, 11:97-107.

3. Michielsen PP, Francque SM, Van Dongen JL: Viral hepatitis and hepatocellular carcinoma. World J Surg Oncol 2005, 3:1-18.

4. Seeger C, Mason WS: Hepatitis B virus biology. Microbiol Mol Biol Rev 2000, 64:51-68.

5. Ayoola EA: Viral Hepatitis in Africa. Viral Hepatitis and Liver Disease New York, NYAlan R Liss, Inc 1988, 161-169.
6. Bekondi C, Olinger CM, Boua N, Talarmin A, Muller CP, Le Faou A, Venard V: Central African Republic is part of the West-African hepatitis $B$ virus genotype E crescent. J Clin Virol 2007, 40:31-37.

7. Bélec L, Grésenguet G, Georges-Courbot MC, Villon A, Martin MH, Georges AJ: Sero-epidemiological study of several sexually transmitted diseases (including HIV infection) in rural zone of Central African Republic. Bull Soc Pathol Exot 1988, 81:692-698.

8. Pawlotsky JM, Bélec L, Grésenguet $G$, Deforges L, Bouvier M, Duval J, Dhumeaux D: High prevalence of hepatitis B, C, and E markers in young sexually active adults from the Central African Republic. J Med Virol 1995, 46:269-273.

9. Komas NP, Gody J, Béré A, et al: Seroprevalence and age acquirement of HBV infection during childhood in Complexe Pediatrique de Bangui (Central African Republic) [abstract]. J Clin Virol 2006, 36(S2):S199.

10. Bellis MA, Hughes K, Calafat A, Juan M, Ramon A, Rodriguez JA, Mendes F, Schnitzer S, Phillips-Howard P: Sexual uses of alcohol and drugs and the associated health risks: a cross sectional study of young people in nine European cities. BMC Public Health 2008, 8:155.

11. Heng BH, Goh KT, Chan R, Chew SK, Doraisingham S, Quek GH: Prevalence of hepatitis $B$ virus (HBV) infection in Singapore men with sexually transmitted diseases and HIV infection: role of sexual transmission in a city state with intermediate HBV endemicity. J Epidemiol Community Health 1995, 49:309-13.

12. Gjorup IE, Skinhoj P, Böttiger B, Plesner AM: Changing epidemiology of HBV infection in Danish children. J Infect 2003, 47:231-235.

13. Su F-H, Chen J-D, Cheng S-H, Lin C-H, Liu Y-H, Chu F-Y: Seroprevalence of hepatitis-B infection amongst Taiwanese University students 18 years following the commencement of a national hepatitis- $B$ vaccination program. J Med Virol 2007, 79:138-143.

14. Villa E, Cartolari R, Bellentani S, Rivasi P, Casolo G, Manenti F: Hepatitis B virus markers on dried blood spots. A new tool for epidemiological research. J Clin Pathol 1981, 34:809-812.

15. Backmund M, Meyer K, Schuetz C, Reimer J: Factors associated with exposure to hepatitis B virus in injection drug users. Drug Alcohol Depend 2006, 84:154-159.

16. Mele A, Mariano A, Tosti ME, Stroffolini T, Pizzuti R, Gallo G, Ragni P, Zottit C, Lopalco P, Curtale F, Balocchini E, Spada E, SEIEVA Collaborating Group: Acute hepatitis delta virus infection in Italy: incidence and risk factors after the introduction of universal anti-hepatitis $B$ vaccination campaign. Clin Infect Dis 2007, 44:e17-24.

17. Mendy M, Kirk GD, Van der Sande $M$, Jeng-Barry A, Lesi OA, Hainaut $P$, Sam O, McConkey S, Whittle H: Hepatitis B surface antigenaemia and alpha-foetoprotein detection from dried blood spots: application to field-based studies and to clinical care in hepatitis B virus endemic areas. J Viral Hepat 2005, 12:642-647.

18. McQuillan GM, Townsend TR, Fields HA, Carroll M, Leahy M, Polk BF: Seroepidemiology of hepatitis B virus infection in the United States. 1976 to 1980. Am J Med 1989, 87(3A):5S-10S.

19. Gogos CA, Fouka KP, Nikiforidis G, Avgeridis K, Sakellaropoulos G, Bassaris H, Maniatis A, Skoutelis A: Prevalence of hepatitis $B$ and $C$ virus infection in the general population and selected groups in south-Western Greece. Eur J Epidemiol 2003, 18:551-557.

20. Bonanni P, Pesavento G, Bechini A, Tiscione E, Manuelli F, Benucci C, Nostro AL: Impact of universal vaccination programmes on the epidemiology of hepatitis B: 10 years of experience in Italy. Vaccine 2003, 21:685-691.

21. Salleras L, Dominguez A, Bruguera M, Cardenosa N, Batalla J, Carmona G, Navas E, Taberner JL: Dramatic decline in acute hepatitis B infection and disease incidence rates among adolescents and young people after 12 years of a mass hepatitis B vaccination programme of pre-adolescents in the schools of Catalonia (Spain). Vaccine 2005, 23:2181-2184.

22. Oliveira MD, Martins RMB, Matos MA, Ferreira RC, Dias MA, Carneiro MAS, Junqueira ALN, Teles SA: Seroepidemiology of hepatitis B virus infection and high rate of response to hepatitis $B$ virus Butang vaccine in adolescents from low income families in Central Brazil. Mem Inst Oswaldo Cruz (Rio de Janeiro) 2006, 101:251-256.

23. Alhababi F, Sallam TA, Tong CY: The significance of "anti-HBc only" in the clinical virology laboratory. J Clin Virol 2003, 27:162-169.

24. Jaber SM: Prevalence of anti-hepatitis B and anti-hepatitis A antibodies among school aged children in Western Saudi Arabia. Saudi Med J 2006, 27:1515-1522. 
25. Shepard CW, Simard EP, Finelli L, Fiore AE, Bell BP: Hepatitis B virus infection: epidemiology and vaccination. Epidemiol Rev 2006, 28:112-125.

26. Mast EE, Weinbaum CM, Fiore AE, Alter MJ, Bell BP, Finelli L, Rodewald LE, Douglas JM Jr, Janssen RS, Ward JW: A comprehensive immunization strategy to eliminate transmission of hepatitis $B$ virus infection in the United States: recommendations of the Advisory Committee on Immunization Practices (ACIP) Part II: immunization of adults. MMWR Recomm Rep 2006, 55:1-33.

\section{Pre-publication history}

The pre-publication history for this paper can be accessed here: http://www.biomedcentral.com/1471-2334/10/226/prepub

doi:10.1186/1471-2334-10-226

Cite this article as: Komas et al:: The prevalence of hepatitis B virus markers in a cohort of students in Bangui, Central African Republic. BMC Infectious Diseases 2010 10:226.

\section{Submit your next manuscript to BioMed Central} and take full advantage of:

- Convenient online submission

- Thorough peer review

- No space constraints or color figure charges

- Immediate publication on acceptance

- Inclusion in PubMed, CAS, Scopus and Google Scholar

- Research which is freely available for redistribution

Submit your manuscript at www.biomedcentral.com/submit 